\title{
Customer Satisfaction, Trust and Loyalty as Predictors of Customer Intention to Re-Purchase South African Retailing Industry
}

\author{
Richard Chinomona \\ Department of Logistics, Vaal University of Technology \\ Private Bag X021, Vanderbijlpark 1900, South Africa \\ E-mail:rchinos@hotmail.com
}

Maxwell Sandada

Vaal University of Technology, South Africa

Doi:10.5901/mjss.2013.v4n14p437

\begin{abstract}
Notwithstanding the increasing researches on consumer behaviour, there is a dearth of studies that have investigated the influence of customer satisfaction on customer trust, loyalty and repurchase intention in the African retailing context. Therefore, using a data set of 151 from athletes in Gauteng Province of South Africa, this study examines these relationships. All the posited four hypotheses are supported. The results indicate that the relationship between customer satisfaction and their trust, customer satisfaction and their loyalty, customer trust and their loyalty, customer loyalty and their repurchase intention are positive in a significant way. The research paper discusses both academic and managerial implications of the results and future research directions are suggested.
\end{abstract}

Keywords: Customer satisfaction; Customer trust; Customer loyalty; Customer repurchase intention; South Africa

\section{Introduction}

Customer repurchase intention is of paramount importance to business practitioners because it is an indication of business continuity, future revenue generation prospects and hence business profitability (Chang, 2012). Consequently, both business practitioners and academicians alike have been interested in identifying the antecedents of customer repurchase intention. Interestingly to note, customer satisfaction, trust and loyalty are consistently among some of the factors that have increasingly being recognised in the extant literature as predictors of customer intention to re-purchase (Lin \& Wang, 2006; Hui, Kandampully \& Juwaheer, 2009; Hong \& Cho, 2011; Sirdeshmurk, Sigh and Sabel, 2012). The importance of these factors is well documented in the retail literature, especially in Europe, the USA and Asia (Olaru, Purchase \& Peterson, 2008; Boshoff \& du Plessis, 2009; Huddleston, Whipple, Mattick\& Lee, 2009; Hong \& Cho, 2011; Dabholkar \& Sheng, 2012). These researchers show that it is crucial for businesses to provide products or services that satisfy customers because satisfied customers develop trust in the service provider and become loyal and as a result make repeat purchases. Moreover, these factors are regarded too as key success factors to achieve competitive advantage in the retail industry (Kang, Okamoto \& Donovan, 2004; Hui, Kandampully \& Juwaheer, 2009; Hamadi, 2010).

However, although previous empirical studies that examine the behavioural outcomes of customer satisfaction, customer trust and customers' loyalty are rampant - particularly in the developed parts of the world, two main research gaps are identified by the current study. First, the previous studies have by and large sought to investigate the direct influence of these variables on each other or their influence on consumer purchase intention (e.g. Ou \& Sia, 2003; Hui et al., 2009; Chang, 2012). They appear to be a void of empirical studies that investigate the mediating influence of customer trust and loyalty in the customers' satisfaction - customers' repurchase intentions relationship. This study seeks to fill in this identified research gap. Second, as noted earlier on, most of these studies have been conducted in the developed or newly developed parts of the world such as countries in Europe, the USA or Asia. Conspicuously, hardly can one find studies on the same in the African context. Perhaps, it might not be judicious to assume a-priori that the findings from the developed parts of the Word can apply in the African context. Therefore, the current study seeks too, to confirm or disconfirm the previous findings from developed countries in the African context - in particular, using South Africa as a case in point. 
The contributions of this study are expected to be academic and practical oriented. For instance, exploring the influence of customer satisfaction on their trust, loyalty and re-purchase intentions will provide practical basis and motivations for retailers in South Africa to adopt strategies targeted at satisfying customers in order to gain their trust and loyalty - which ultimately is noted to lead to customer repurchase intention. On the academic front, the current study is expected to generate new literature on customer repurchase intention predictors from an African perspective.

The rest of the paper is arranged as follows: A theoretical review, the conceptual framework and hypotheses will firstly be presented. Thereafter the methodology, data analysis and conclusions are discussed. The final section presents the managerial implications, limitations and recommendations for future research.

\section{Literature Review}

\subsection{Customer satisfaction}

Given the intense competitive business world and the increase in consumer awareness, customer satisfaction has become a crucial issue among scholars and practitioners. Therefore, in order to remain competitive and sustainable, marketers need to make sure that they satisfy their customers. It has been proven that customer satisfaction positively influences repurchase intention (Lee, 2004; Huddleston, Whipple, Mattick\& Lee, 2009), it is an important predictor of customer loyalty (Cheng, Chiu, Hu \& Chang, 2011) and it also positively impacts on customer trust (Dabholkar \& Sheng, 2012). Scholars such as Chenget al. (2011) argue that satisfying a customer is even more important than profit making. The authors reasoned that satisfying a customer precedes profit making, hence as long as customers are satisfied, the business will make profit. Customer satisfaction has therefore become an important measure of the behaviour of consumers (Cheng et al., (2011) and a key indicator of business performance (Sandada 2013).

Chang (2006) views customer satisfaction as a post consumption evaluation of a product or a service and defines it as the ability of an organisation to provide a service performance that exceeds the customer expectations.Deng, Lu, Wei and Zhang (2010) state that customer experiences cumulative satisfaction after having a good experience of using the product or service. The authors also group satisfaction into two types: the transaction specific satisfaction and the general satisfaction. While the former refers to satisfaction after a given service encounter, the latter describes the consumers' overall rating of the service or product based on previous experiences (Deng et al., 2010). For Hwang and Zhao (2010), customer satisfaction occurs when there is confirmation and positive disconfirmation of customer expectations. It implies that customers are satisfied when their expectations are met and when their expectations are not met but they still feel good about the performance. Choi and Sheel's (2012) definition include the output and process aspects of customer satisfaction. The output definition views customer satisfaction as a cognitive or mental state in which consumers feel that they have been adequately or inadequately compensated. Regarding the process, customer satisfaction occurs when customer experience matches or exceeds the expectations. Consumer evaluation therefore is crucial customer satisfaction (Choi \&Sheel, 2012). In order to satisfy consumers, retailers need to understand the motivations for shopping because customers gain satisfaction from diverse shopping aspects (Huddlestonet al., 2009). Some of the motivations for consumer shopping mentioned by Huddleston et al. (2009) are task oriented while others are activity oriented and they include shopping to divert from daily routine, to learn more about trends and new products, to enjoyment bargaining. The definitions discussed above show that customer satisfaction is an outcome of an evaluation by customers on the service provided against their expectations.

\subsection{Customer trust}

Customer trust is confidence that customers have in the reliability and competence of service providers (Boshoff \& du Plessis, 2009). According to Chang (2012) customer trust consists of affective and cognitive trust. In cognitive trust consumers are confident that the service provider is competent and reliable in keeping promises, whereas in affective trust consumers believe that while the service providers seek to maximise profits they also have genuine concern for customer needs. Dabholkar and Sheng (2012) believe that customers trust service providers if they believe that the product or service provides benefits to them. Customer trust influences the development of consumer commitment to the service provider because of the positive experiences they had with the product or service (Olaru, Purchase \& Peterson, 2008). This indicates that retailers need to make sure that the service encounters satisfy customers in order to ensure commitment by consumers. Echoing the same sentiments, Boshoff and du Plessis (2009) assert that customer trust is a key component of relationship building. Customer trust involves taking a certain degree of risk as customers are 
vulnerable to the service providers (Hong \& Cho, 2011). Therefore to gain customer trust, the retailing industry should be reliable and competent in service provision.

\subsection{Customer loyalty}

Due to intense competition in the market place, businesses have increased efforts to implement the customer retention strategy in order to maximise the lifetime value of customers (Boshoff\& du Plessis, 2009). According to Deng, Lu, Wei, Zhang (2010) customer loyalty refers to commitment by customers to make consistent repeat purchases of a preferred brands or services in spite of situational and marketing efforts to influence switching behaviour.For Cheng et al. (2011) customer satisfaction means creating and maintaining long term relationships with customers. Hong and Cho (2011) assert that customer loyalty indicates the consumers' psychological attachment to the product as well as attitudinal advocacy towards the business. Through strengthened customer loyalty, businesses are able to retain customers and consequently profits increase (Lee, 2010). This complies with a suggestion by Deng et al. (2010) who pointed out that customer loyalty is a predictor of long term viability of the firm as loyal customers are not influenced by bad publicity and they provide free word of mouth advertising and referrals. Cheng et al. (2011) proposed that it is cost-effective to maintain existing customers than obtaining new ones. To this the authors proceeded to state that the cost of developing a new customer is between 5 and 9 times the cost of maintaining the existing customers. This demonstrates that retailers need to retain loyal customers because through cost-effectiveness there are high chances of survival and strong future growth. According to Boshoff and du Plessis (2009) the benefits of customer loyalty are that loyal customers: are cheap to maintain, are price insensitive, spread free positive word of mouth, always provide suggestions and they always try new products.

\subsection{Customer intention to re-purchase}

In the face of competitive market conditions, businesses need to deliver consumer value by engaging customers in long term relationships in order to increase chances of re-purchase (Mai \& Ness, 2006). The intention to re-purchase is a post purchase behavioural intention that influences customer loyalty, complaint and switch intentions (Meng, Liang \& Yang, 2011). The switch intention show the intention by the customer to try other brands, while the complaint intention indicates that customers are unhappy and inform about the problems and may seek for compensation or may boycott purchase. The loyalty intention represents the commitment by customers to the brand and their willingness to have long term relationships. Therefore the best strategy to deal with complaint and switching behaviour is to satisfy the customers. The intention of consumers to re-purchase is dependent on customer evaluation of the previous purchase transactions (Bansal, Irving \& Taylor, 2008). Olaru et al. (2008) state that, when evaluating their previous experiences, consumers usually consider factors such as product performance and the cost and benefits derived from the products. Hamadi (2010) echoes the same sentiments by stating that satisfied customers become prone to return for repeat purchases and they resist the influences of competing brands. For this to happen, Hamadi (2010) recommends that consumers should be especially pleased.

\section{Conceptual Framework and Hypothesis}

Figure 1 shows the conceptual model depicting the four variables. It is submitted according to the conceptualized research model that: Delivering services that achieve customer satisfaction can create trust and loyalty. The trusting beliefs in the business increase customer loyalty levels which eventually affect their re-purchase intention. The development of the hypotheses is discussed in the following sections.

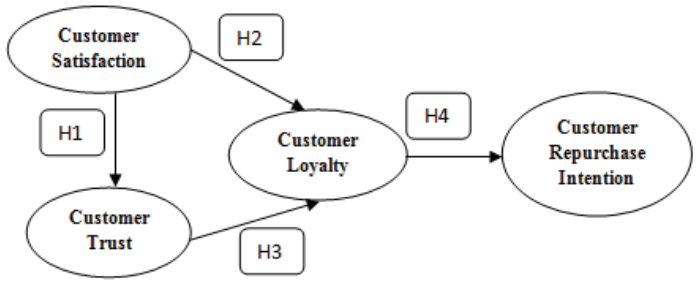

Figure 1 Conceptual framework 


\subsection{Customer satisfaction and customer trust}

Literature shows bi-directional relationships between satisfaction and trust. The reason is that no general consensus among scholars exists as to which between these variables is a dependent and independent variable. For example Lin and Wang (2006) and Chang (2012) propose that trust precedes satisfaction. What it means is customers trust the service providers probably basing on their image rather that the experience. This study argues that customers firstly deal with the business and evaluate the business based on those experiences. If the experiences meet their expectations then they become satisfied and will later on trust the business. Therefore this study considers satisfaction as the predictor of trust. This argument was supported by Dabholkar and Sheng (2012) who tested the effect of satisfaction on trust with the context of online business transactions. The implication is that due to satisfying experiences with the business, customers begin to have trusting beliefs about the service provider (Dabholkar \& Sheng, 2012). The influence of customer satisfaction on customer trust has also been confirmed by a study by Ou and $\operatorname{Sin}$ (2003) who recommended that in order to strengthen customer trust of internet customers, e-retailers need to firstly satisfy internet shoppers on privacy and security issues. This demonstrates the effect of satisfaction on trust. Similarly, Olaru et al. (2008) assert that the positive experiences that customers have lead to satisfaction and the satisfying experiences consequently result in customer trust. The assertion by Boshoff and du Plessis (2009) that trust is crucial in relationships means that customers need to have prior pleasing experiences leading to satisfaction and which eventually leads to trust. Therefore deducing from the foregoing discussion, it is hypothesized that:

H1. Higher levels of customer satisfaction are positively associated with higher levels of customer trust

\subsection{Customer satisfaction and customer loyalty}

Bansawl et al. (2004) suggested that satisfied customers are more likely to use the same service, to resist competing brands and spread positive word of mouth. The study of online banking in Morocco by Hamadi (2010) found a positive relationship between customer satisfaction and customer commitment and loyalty. In their study of Chinese instant message industry, Deng et al. (2011) also found that customer satisfaction is a significant predictor of customer trust. The results corroborate the findings of a study of Taiwanese fast food industry which show that satisfied customers become loyal to the brand. This demonstrates that to create and maintain customer loyalty, retailers should satisfy customer expectations. This is further supported by Lee (2010) whose study of predictors of customer loyalty in the Korean mobile phones found a positive relationship between customer satisfaction and customer loyalty. In addition, based on research studies by Lin and Wangs (2006) and Avramakis (2011), customer satisfaction positively influences customer loyalty. Therefore it is proposed that:

H2. Higher levels of customer satisfaction are positively associated with higher levels of customer loyalty

\subsection{Customer trust and customer loyalty}

When customers trust the service provider, they are likely to be loyal towards the service provider (Deng et al. 2010). According to Hong and Cho (2011) the trustworthiness of a business plays a critical role in creating and maintaining customer loyalty. The study of Bansal et al. (2004) showed that there is a significant positive relationship between customer trust and loyalty. The results are compatible with those of other studies by Yee (2004) and Lin and Wang (2006). Avramakis (2011) studied the customer relationships in the Swiss Financial system and reported that customer trust positively predicts customer loyalty. This positive relationship was also substantiated by Sirdeshmurk, Sigh and Sabel (2012) who developed a framework of understanding customer trust and loyalty relationship in the airline and retailing industry. The results of the study indicate trustworthy behaviour by consumers directly influence trust. The authors argued that when the service providers manage to build customer trust, customers do perceive low risk and will have more confidence in the service provider's reliability and integrity and as a result become loyal. Deng et al. (2010) argues that achieving a customer trust is the main contributor to customer loyalty. Therefore this study proposes that:

H3. Higher levels of customer trust are positively associated with higher levels of customer loyalty

\subsection{Customer loyalty and customer intention to re-purchase}

High levels of overall satisfaction will lead to customer trust and loyalty and this ultimately could attract more customers to make repeat purchases (Kang et al., 2004). Deng et al. (2010) also stated that customer loyalty was the main factor 
predicting intention to re-purchase. The negative relationship between continuance commitment and switching intentions in a study by Bansal et al. (2004) shows that customer commitment results in intention to continue buying from the service provider. A study by Meng et al. (2011) of post-behavioural intention of Taiwanese tourists found a positive relationship between the image of the service provider and the intention to repurchase. The reason was that the customers became loyal to the service provider and hence indicating that loyalty leads to repurchase intention. Based on the above, the hypothesis proposed is as follows:

H4. Higher levels of customer loyalty are positively associated with higher levels of customer repurchase intention

\section{Research Methodology}

\subsection{Sample and data collection}

The target population for the study was South African consumer in Gauteng who purchased any consumer goods. The sampling unit was the individual consumer. A mall intercept survey was used. This method has the advantage of speed, is less costly and the researcher has control over respondent type. The participants had approximately 10 minutes to complete the questionnaires. All surveyors used the same written protocol and they were trained to use the same words. It was also explained that responses would remain anonymous as only a numerical key could identify each subject's response sheets in the questionnaires. No remuneration or other incentives were offered and participation was anonymous and voluntary. Of the total of 170 questionnaires distributed, 151 usable questionnaires were retrieved for the final data analysis, representing a response rate of 89 per cent.

\subsection{Measurement Instrument and Questionnaire Design}

Research scales were operationalized on the basis of previous work. Proper modifications were made in order to fit the current research context and purpose. "Customer satisfaction" measure used four-item scales adapted from Chinomona and Cheng (2013) and Sahin, Zehir and Kitapçi (2011). "Customer trust" and "customer loyalty" used a four-item scale measure adopted from Chaudhuri and Holbrook (2001). Finally, "customer repurchase intention" used three-item scale measure all adapted from Hellier, Geursen, Carr and Rickard (2003). All the measurement items were measured on a five-point Likert-type scales that was anchored by $1=$ strongly disagree to $5=$ strongly agree to express the degree of agreement.

\subsection{Respondent Profile}

The respondents were asked to report their demographic information, including gender, age, marital status and education. Out of a sample set of 151, the majority of the respondents females (59.5\%). The median age group of the respondent was that of less than 30 years (55.4\%). $58 \%$ of the respondents were single. About $79.4 \%$ of the respondents had either high school (53\%) or university level of education (26.4\%) and the remainder had primary school (14.9\%) or postgraduate level of education (5.7\%).

\section{Data Analysis}

\subsection{Structural Equation Modeling Approach}

In order to statistically analyze the measurement and structural models, this study used Smart PLS software for Structural Equation Modeling (SEM) technique (Ringle, Wende \& Will, 2005). In SEM, the measurement model refers to the linkages between the latent variables and their manifest variables and the structural model captures the hypothesized causal relationships among the research constructs (Chin \& Newsted, 1999). SEM enables the simultaneous examination of both the path (structural) and factor (measurement) models in one model. In addition to that, Smart PLS combines a factor analysis with near regressions, makes only minimal assumptions, with the goal of variance explanation (high R-square) (Chin, 1998). Furthermore, Smart PLS supports both exploratory and confirmatory research, is robust to deviations for multivariate normal distributions, and is good for small sample size. Since the current study sample size is relatively small (233) Smart PLS was found more appropriate and befitting the purpose of the current study. 


\subsection{Measurement Model}

A measurement model of the conceptual model with five latent variables was estimated. All constructs were modelled using reflective indicators since the previous study have modelled them the same. Construct reliability was assessed using Composite Reliabilities (CR) values and Cronbach's Alpha (CA) values. As indicated in Table 2, the CR and the CA values are all above 0.6 recommended by Hulland (1999). With values ranging from 0.863 to 0.922 for Composite reliability and from 0.798 to 0.887 for all Cronbach's alphas, this study can conclude that the scales are reliable.

Table 2: Accuracy Analysis Statistics

\begin{tabular}{|c|c|c|c|c|c|c|c|c|}
\hline \multicolumn{2}{|c|}{$\begin{array}{l}\text { Research } \\
\text { Construct }\end{array}$} & $\begin{array}{l}\text { LV Index } \\
\text { Value }\end{array}$ & $\begin{array}{l}\text { R-Squared } \\
\text { Value }\end{array}$ & $\begin{array}{c}\text { Cronbach's } \alpha \\
\text { value }\end{array}$ & $\begin{array}{l}\text { C.R. } \\
\text { Value }\end{array}$ & $\begin{array}{l}\text { AVE } \\
\text { Value }\end{array}$ & Communality & $\begin{array}{c}\text { Factor Item } \\
\text { Loading }\end{array}$ \\
\hline \multirow{4}{*}{ CS } & CS 1 & \multirow{4}{*}{4.563} & \multirow{4}{*}{0.000} & \multirow{4}{*}{0.798} & \multirow{4}{*}{0.863} & \multirow{4}{*}{0.612} & \multirow{4}{*}{0.612} & 0.769 \\
\hline & CS 2 & & & & & & & 0.825 \\
\hline & CS 3 & & & & & & & 0.732 \\
\hline & CS 4 & & & & & & & 0.801 \\
\hline \multirow{4}{*}{ CT } & CT 1 & \multirow{4}{*}{4.449} & \multirow{4}{*}{0.411} & \multirow{4}{*}{0.869} & \multirow{4}{*}{0.911} & \multirow{4}{*}{0.719} & \multirow{4}{*}{0.719} & 0.849 \\
\hline & CT 2 & & & & & & & 0.893 \\
\hline & CT 3 & & & & & & & 0.865 \\
\hline & CT 4 & & & & & & & 0.780 \\
\hline \multirow{4}{*}{$\mathrm{CL}$} & CL 1 & \multirow{4}{*}{4.457} & \multirow{4}{*}{0.644} & \multirow{4}{*}{0.887} & \multirow{4}{*}{0.922} & \multirow{4}{*}{0.748} & \multirow{4}{*}{0.748} & 0.857 \\
\hline & $\mathrm{CL} 2$ & & & & & & & 0.848 \\
\hline & $\mathrm{CL} 3$ & & & & & & & 0.865 \\
\hline & $\mathrm{CL} 4$ & & & & & & & 0.888 \\
\hline \multirow{3}{*}{ CRI } & CRI 1 & \multirow{3}{*}{4.611} & \multirow{3}{*}{0.254} & \multirow{3}{*}{0.831} & \multirow{3}{*}{0.899} & \multirow{3}{*}{0.747} & \multirow{3}{*}{0.747} & 0.809 \\
\hline & CRI 2 & & & & & & & 0.809 \\
\hline & CRI3 & & & & & & & 0.882 \\
\hline
\end{tabular}

Note: CS = Customer Satisfaction; CT = Customer Trust; CL = Customer Loyalty; CRI = Customer Repurchase Intention

C.R.: Composite Reliability; AVE: Average Variance Reliability, ${ }^{*}$ Scores: 1 - Strongly Disagree; 3 - Neutral; 5 - Strongly Agree

Convergent validity (internal consistence) was assessed using the average variance extracted (AVE) measure and Item loading values. According to Fornell and Lacker's (1981) the suggested benchmark should be 0.5 . As can be noted again in Table 2 and Figure 2, all the item loadings and AVE values reached the recommended benchmark - implying that all items converged well on the construct they were supposed to measure and hence confirming the existence of convergent validity.

Table 3: Inter-Construct Correlations and Shared Variance

\begin{tabular}{|l|l|l|l|l|}
\hline \hline Research Constructs & CS & CT & CL & CRI \\
\hline Customer Satisfaction (CS) & 0.782 & & & \\
\hline Customer Trust (CT) & 0.641 & 0.848 & & \\
\hline Customer Loyalty (CL) & 0.766 & 0.675 & 0.865 & \\
\hline Customer Repurchase Intention (CRI) & 0.810 & 0.524 & 0.504 & 0.864 \\
\hline \hline
\end{tabular}

Note: $\mathrm{HO}=$ Hostility; AN = Anger; VA = Verbal Aggression; PA = Physical Aggression

\subsection{Diagonal elements are the square root of Average Variance Extracted. The other values are the inter-construct} correlations

To assess discriminant validity the AVE of the construct should be greater than the shared variance between the construct and the other model constructs (Chin, 1998). Table 3 lists the correlation matrix with correlation among constructs and the square root AVE on the diagonal. As shown in Table 3, the diagonal elements are greater than the offdiagonal elements in the corresponding rows and columns, therefore confirming that discriminant validity indeed exist. 


\subsection{Structural Modeling Results}

The structural model was tested using the loadings and significance of the path coefficients (indicate the strengths of relationships between dependent and independent variables), and the $\mathrm{R}^{2}$ value (the amount of variance explained by independent variables). The statistical significance of each path was estimated using a Smart PLS bootstrapping method utilizing 300 resamples to obtain t-values (Chin, 1998). The first running of PLS algorithm yielded some unreliable item loading $(<0.5)$. Figure 2 , provides these results. The authors deleted the unreliable items with loadings less than 0.5 and the final measurement and structural model is provided in Figure 3. Table 4 presents the final results of the PLS analysis on the structural model along with the path estimates and t-values. Support for the study hypotheses, which are labelled on their corresponding paths in Figure 2, could be ascertained by examining the directionality (positive or negative) of the path coefficients and the significance of the t-values. The standardized path coefficients are expected to be at least 0.2 , and preferably greater than 0.3 (Chin 1998).

Figure 2: Measurement and Structural Model Results

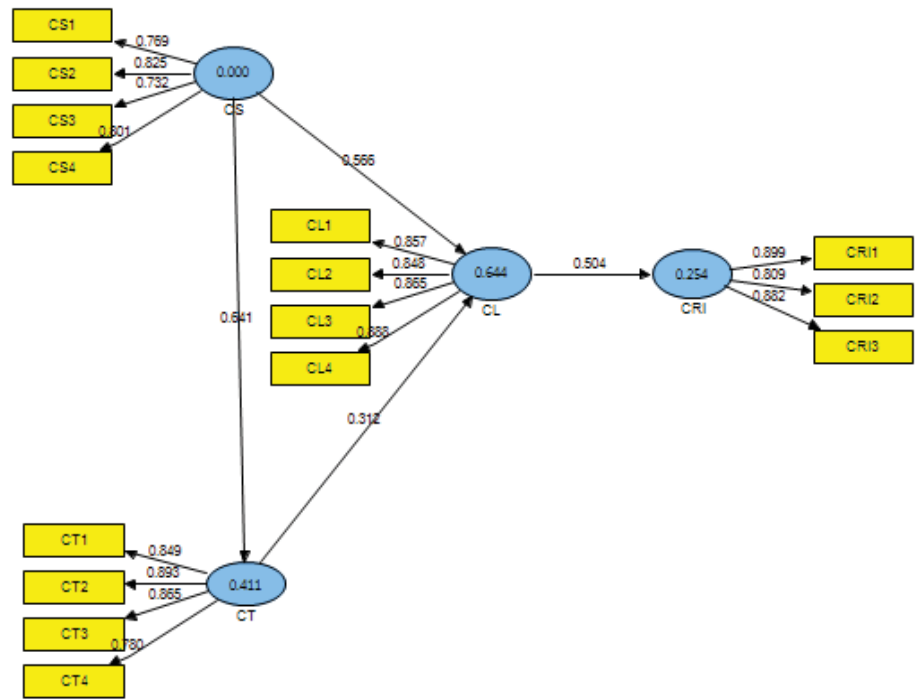

Note: $\mathrm{CS}=$ Customer satisfaction; $\mathrm{CT}=$ Customer trust; $\mathrm{CL}=$ Customer loyalty; $\mathrm{CRI}=$ Customer repurchase intention

The $R^{2}$ values for the dependent variables - customer trust $(C T)$, customer loyalty $(C L)$ and customer repurchase intention (CRI) are $0.411,0.644$ and 0.254 respectively. This result reveal that, on the overall customer trust explains about $41.1 \%$ of customer satisfaction while customer loyalty explains about $64.4 \%$ of both customer trust and customer satisfaction and customer intention to repurchase explains $25.4 \%$ of customer loyalty.

Smart PLS software does not provide goodness-of-fit measures for the full path model as like LISREL and AMOS, but it provides only $\mathrm{R}^{2}$ values for the dependent variables. However, a method to calculate a global goodness-of-fit (GoF) measure was proposed by Amato, Vinzi and Tenenhaus (2004), and this method takes into account both the quality of the measurement model and the structural model (Tenenhaus, Vinzi, Chatelin \& Lauro, 2005). The global goodness-of-fit (GoF) statistic was calculated using the following equation:

$$
\mathrm{GoF}=\sqrt{\overline{\mathrm{AVE}^{*} \mathrm{R}^{2}}-}
$$

Where AVE represent the average of all AVE values for the research variables while $\mathrm{R}^{2}$ represents the average of all $R^{2}$ values in the full path model

The calculated global goodness of fit $(\mathrm{GoF})$ is 0.56 , which exceeds the recommended threshold of $\mathrm{GoF}>0.36$ suggested by Wetzels, Odekerken-Schröder \& van Oppen (2009). Thus, this study concludes that the research model provides an overall goodness of fit. 
Table 4: Results of Structural Equation Model Analysis

\begin{tabular}{|l|c|c|c|c|}
\hline \hline \multicolumn{1}{|c|}{ Proposed Hypothesis Relationship } & Hypothesis & Path Coefficients & T-Statistics & $\begin{array}{c}\text { Supported I } \\
\text { Not Supported }\end{array}$ \\
\hline Customer Satisfaction (CS) $\rightarrow$ Customer Trust (CT) & H1 & 0.641 & 8.740 & Supported \\
Customer Satisfaction (CT) $\rightarrow$ Customer Loyalty (CL) & H2 & 0.566 & 11.274 & Supported \\
Customer Trust (CT) $\rightarrow$ Customer Loyalty (CL) & H3 & 0.312 & 3.774 & Supported \\
Customer Loyalty (CL) $\rightarrow$ Customer Repurchase & H4 & 0.504 & 5.713 & Supported \\
Intention (CRI) & & & \\
\hline \hline
\end{tabular}

Note: $\mathrm{CS}=$ Customer satisfaction; $\mathrm{CT}$ = Customer trust; $\mathrm{CL}=$ Customer loyalty; $\mathrm{CRI}=$ Customer repurchase intention

\section{Discussion of Results}

The results in Table 4 and Figure 2 provide support for four (4) hypotheses ( $\mathrm{H} 1, \mathrm{H} 2, \mathrm{H} 3$ and $\mathrm{H} 4)$. Hypothesis 1 posited a positive relationship between customer satisfaction and customer trust. Consistent with $\mathrm{H} 1$, the result in Table 4 and Figure 2, indicates that there is a significant $(t=8.740)$ positive $(\beta=0.641)$ relationship between customer satisfaction and customer trust. Therefore, $\mathrm{H} 1$ is supported. Hypothesis 2 posited a positive association between customer satisfaction and customer loyalty. Hypothesis 2, results indicated that customer satisfaction is positively associated with customer loyalty $(\beta=0.566)$ and the relationship is significant $(t=11.274)$. This is consistent with the prediction of $\mathrm{H} 2$ and is therefore supported. The standardized coefficient and significant levels of customer trust $(\beta=0.312 ; t=3.774)$ is positive and significant. This is consistent with the prediction of $\mathrm{H} 3$ and is supported. Thus, a higher level of customer trust is associated with higher levels of customer loyalty. Finally, results in Table 4 and Figure 2, are in line with $\mathrm{H} 4$ and support the reasoning that the higher the level of customer loyalty, the higher the likelihood of their intention to repurchase $(\beta=0.504 ; t=5.713)$. Therefore, $\mathrm{H} 4$ is supported.

\subsection{Conclusion}

The purpose of this study was to investigate the influence of customer satisfaction on their trust, loyalty and intention to repurchase. In particular, four hypotheses were postulated. To test the proposed hypotheses, data were collected from Gauteng Province in South Africa. The empirical result supported all the four posited research hypotheses in a significant way.

Important to note about the study findings is the fact that customer satisfaction and customer trust have influence on customer repurchase intention through customer loyalty. This implies that customer satisfaction and trust have stronger influence on customer repurchase intention when they first trigger the customer's loyalty.

\subsection{Implications of the study}

While there is an increased recognition of customer satisfaction as a critical aspect today's competitive business environment, the extant literature is replete with empirical evidence suggesting that customer trust, customer loyalty, and customer repurchase intention are related constructs of customer satisfaction. However, the current study was set to depart from this long held conventional wisdom and attempts to investigate the causal relationships between these constructs in service provision in the retailing industry. In particular, a successful attempt was made in this study to customer satisfaction as the predictor of customer trust, customer loyalty and customer repurchase intention. In addition to that, the current study investigate this contentious issues in an often most neglected research context - the African setting. Therefore, the findings of this empirical study are expected to provide fruitful new insights and implications to both academicians and retailing practitioners across the globe.

On the academic side, this study makes a significant contribution to the customer service and retailing literature by exploring the impact of customer satisfaction on trust, loyalty and repurchase intention in the context of South African one of the newly developed countries on the African continent. In particular, the current study findings provide tentative support to the proposition that customer satisfaction; customer trust and customer loyalty should be recognized as antecedents and tools that precipitate repurchases intention in retailing.

On the practitioners' side, important influential role of customer's satisfaction on their trust and loyalty and consequently their intention to repurchase in an African context are highlighted. Therefore, this study for instance submits that retailing owners or managers seeking to find ways to attract and retain customers should begin to consider this 
behaviour not only as the interplay of customer satisfaction, customer trust, customer loyalty and customer repurchase intention but rather a behaviour that is precipitated by satisfaction and then develops to trust before it manifest itself in the form of loyalty and consequently repurchase intention.

\subsection{Limitations and Future Research}

Although this study makes significant contributions to both academia and practice, it was limited in some ways, and therefore some future research avenues are suggested. First, the data were gathered from Gauteng Province of South Africa and the sample size of 233 is relatively small. Perhaps, the results would be more informative if the sample size is large and data gathered from the other eight provinces of the country are included. Therefore, future studies may be conducted by using data from other provinces in South Africa. Second, perhaps too, future studies should not be limited to South Africa, but rather consider extending this research to other African countries such as Zimbabwe for results comparison. Future studies can also extend the current study by studying the relationships in the current conceptual model in other sectors of the economy. Above and beyond, this will immensely contribute new knowledge to the existing body of consumer purchase behaviour in the retailing industry literature in the African setting - a research context which happens to be neglected in academics.

\section{References}

Amato. S., Esposito V.V. \& Tenenhaus, M. (2004). A global goodness-of-fit index for PLS structural equation modeling, France: Oral Communication to PLS Club, HEC School of Management.

Avramakis, E. 2011.Relationship Management in Swiss Finance Services: An Investigation into Relationship and Bonding Values of Highly-involved and Confident Customers. A Doctor of Business of Administration Thesis. Southern Cross University. Australia.

Aye, G.C., Balcilar, M., Gupta, R. \&Majumdar, A. 2013.Forecasting Aggregate Retail Sales: The Case of South Africa.University of Pretoria Department of Economics Working Paper Series 2.

Bansal, H.S., Irving, P.G. \& Taylor, S.F. 2004. A Three-Component Model of Customer Commitment to Service Providers. Journal of the Academy of Marketing Science, 32 (3):234-245.

Boshoff, C. \& du Plessis, F. 2009. Services Marketing: A Contemporary Approach. Juta and Company Ltd. Cape Town.

Chaudhuri, A., \& Holbrook, B.M. (2001). The Chain of Effects From Brand Trust and Brand Affects to Brand Performance: The Role of Brand Loyalty. Journal of Marketing, 65, 81-93

Chang, J.C. 2006. Customer Satisfaction with Tour Leaders' Performance: A Study of Taiwan's Package Tours. Asia Pacific Journal of Tourism Research, 11(1):97-116.

Cheng, C.C., Chiu, S.I., Hu, H.Y. \& Chang, Y.Y. 2011. A study on Exploring the Relationship Between Customer and Loyalty in the Fast Food Industry: With Relationship Inertia as a Mediator. African Journal of Business Management, 5(13):5118-5126.

Chin, W.W. (1998). Issues and opinion on structural equation modelling, MIS Quarterly, 22 (1), 7-16

Chin, W.W, \& Newsted, P.R. (1999). Structural Equation Modeling analysis with Small Samples Using Partial Least Squares. In Rick Hoyle (Ed.), Statistical Strategies for Small Sample Research, Sage Publications, pp. 307-341. Thousand Oaks, CA: Sage

Chinomona, R \& Cheng, J.M-S. (2013). Distribution Channel Relational Cohesion Exchange Model: A Small-to-Medium Enterprise Manufacturer's Perspective. Journal of Small Business Management, 51(2), 256-275

Choi, C. \&Sheel, A. 2012. Assessing the Relationship Between Waiting Services and Customer Satisfaction in Family Restaurants. Journal of Quality Assurance in Hospitality \& Tourism, 13:24-36.

Dabholkar, P.A. \& Sheng, X. 2012. Consumer Participation in Using Online Recommendation Agents: Effects on Satisfaction, Trust, and Purchase Intentions. The Service Indusries Journal, 32(9):1433-1449.

Deng, Z., Lu, Y., Wei, K, K. \& Zhang, J. 2010.Understanding Customers Satisfaction and Loyalty: An empirical study of mobile Instant messages in China. International Journal ofInformation Management, 30(2010):289-300.

Fornell, C., \& Larcker, D.F. (1981). Evaluating structural equation models with unobservable variables and measurement error. Journal of Marketing Research, 27, 39-50.

Hamadi, C. 2010. The Impact of Quality of Online Banking on Customer Commitment.Communications of the IBIMA, 2010: 1-8.

Hellier, P.K., Geursen, G.M., Carr, R.A. \& Rickard, J.A. (2003). Customer repurchase intention: a general structural equation Model. European journal of marketing, 37, (11), 1762-1800

Hu, H.H., Kandampully, J. \&Juwaheer, T.D. 2009. Relationships and Impacts of Service Quality, Customer Satisfaction, and Image: An Empirical Study. The Service Industry Journal, 29(2): 111-125.

Hulland, J. (1999). Use of Partial Least Squares (PLS)' in Strategic Management Research: A Review of Four Recent Studies. Strategic Management Journal, 20 (2): 195-204.

Hwang, J. \& Zhang, J. 2010.Factors Influencing Customer Satisfaction or Dissatisfaction in the Restaurant Business Using AnswerTree Methodology.Journal of Quality Assurance in Hospitality and Tourism, 11:93-110.

Hong, I.B. \& Cho, H. 2011. The Impact of Consumer Trust on Attitudinal Loyalty and Purchase Intention in B2C E-marketplace: Intermediary Trust vs Seller Trust. International Journal of Information Management, 31(2011):469-479. 
Huddleston, P., Whipple, J., Mattick, R.N. \& Lee, S.J. 2009. Customer Satisfaction in Food Retailing: Comparing specialty and conventional grocery stores. International Journal of Retail and Distribution Management, 37(1):63-80.

Hwang, J. \& Zhang, J. 2010.Factors Influencing Customer Satisfaction or Dissatisfaction in the Restaurant Business Using AnswerTree Methodology.Journal of Quality Assurance in Hospitality and Tourism, 11:93-110.

Kang, S.S., Okamoto, N. \& Donovan, H.A. 2004. Service Quality and its Effect on Customer Satisfaction and Customer Behavioural Intentions: Hotel and Ryokan Guests in Japan. Asia Pacific Journal of Tourism Research, 9(2):2004.

Lee, H.S. 2010. Factors Influencing Customer Loyalty of Mobile Service: Empirical Evidence from Koreans. Journal of International Banking and Commerce, 15(2):1-14.

Lin, H.H. \& Wang, Y.S. 2005. An Examination of the Determinants of Customer Loyalty in Mobile Commerce Contexts. Information and Management, 43:271-282.

Mai, L.W. \& Ness, M.R. 2006. A Structural Equation Model of Customer Satisfaction and Future Purchase of Mail-Order Speciality Food. International Journal of Business Science and Applied Management, 1(1):1-14.

Meng, S.M., Liang, G.S. \& Yang, S.H. 2011. The Relationships of Cruise Image, Perceived Value, Satisfaction, and Post-Purchase behavioural Intention on Taiwanese Tourists. African Journal of Business Management, 5(1):19-29.

Olaru, D., \& Purchase, S. \& Peterson, N. 2008. From Customer Value to Repurchase Intentions and Recommendations.Journal of Business and Industrial Marketing, 23(8):558-565.

Ou, C.X. \&Sia, C.L. 2003.Customer Loyalty Strategy in the Internet Era. $7^{\text {th }}$ Pacific Asia Conference on Information Systems, 10-13 July, Adelaide, South Australia.

Ringle, C. M., Wende, S., \& Will, A. (2005). SmartPLS 2.0 M3. Available at http:// www.smartpls.de

Sahin, A., Zehir, C., \& Kitapçi, H. (2011). The Effects Of Brand Experiences, Trust And Satisfaction On Building Brand Loyalty; An Empricial Research On Global Brands, The 7th International Strategic Management Conference, Paris-France.

Sandada, M. 2013. Strategic Planning and its Relationship with the Performance of Small and Medium sized enterprises in Gauteng. Unpublished Doctoral Dissertation.Vaal University of Technology, Johannesburg. South Africa.

Tenenhaus, M., Vinzi, V. E., Chatelin, Y. -M., \& Lauro, C. (2005). PLS Path Modeling. Computational Statistics and Data Analysis, 48(1), $159-205$.

Wetzels, M., Odekerken-Schröder, G., \& Van Oppen, C. (2009). Using PLS path modeling for assessing hierarchical construct models: guidelines and empirical illustration. Management Information Systems Quarterly, 33(1), 177-195. 